\title{
Heavy Metal Transport in a River-Reservoir System: a Case Study from Central Poland
}

\author{
Mariusz Sojka1 $^{1}$, Marcin Siepak ${ }^{2 *}$, Joanna Jaskuła ${ }^{1}$, Joanna Wicher-Dysarz ${ }^{3}$ \\ ${ }^{1}$ Institute of Land Improvement, Environmental Development and Geodesy, Faculty of Environmental Engineering and \\ Spatial Management, Poznań University of Life Sciences, Poznań, Poland \\ ${ }^{2}$ Department of Hydrogeology and Water Protection, Faculty of Geographical and Geological Sciences, \\ Adam Mickiewicz University, Poznań, Poland \\ ${ }^{3}$ Department of Hydraulic and Sanitary Engineering, Faculty of Environmental Engineering and Spatial Management, \\ Poznań Univeristy of Life Sciences, Poznań, Poland
}

Received: 30 June 2017

Accepted: 10 September 2017

\begin{abstract}
The aim of this study was to analyze the heavy metals transport in a river-reservoir system. Sediment samples from 25 locations ( 9 from the Powa River and 16 from the Stare Miasto Reservoir) were analyzed for trace metals contents $(\mathrm{Cr}, \mathrm{Ni}, \mathrm{Cu}, \mathrm{Zn}, \mathrm{Cd}$, and $\mathrm{Pb}$ ). The relationships between heavy metal concentrations and bottom sediment physical properties were determined with the use of the multivariate statistical techniques cluster analysis (CA), principal component analysis (PCA), and canonical correspondence analysis (CCA). The results showed that concentrations of heavy metals in the sediments of the reservoir were higher than those in the bottom sediments of the river. Concentrations of heavy metals in bottom sediments in the river above the reservoir were characterized by lower spatial variability. Decisive influence on heavy metal concentrations of bottom sediments had silt, clay, and total organic matter content.
\end{abstract}

Keywords: Powa River, reservoir, bottom sediment, heavy metals, multivariate statistical techniques

\section{Introduction}

The development of dams alters the structure and function of river ecosystems. Dam reservoirs have an impact on flow regime, sediment transport, and water quality. Damming a river decreases water velocity, which leads to an increase in suspended sediments deposition. Reservoirs often are described as water treatment plants because they trap water contaminants and suspended sediments. Suspended sediments are the principal factor for heavy metals transport [1-2]. Human activity increased

*e-mail: marcin.siepak@amu.edu.pl input of heavy metals to water bodies where sediments are deposited [3-8]. Amin et al. [9] and Zheng et. al. [10] reported that more than $90 \%$ of the heavy metal load in the water bodies has been associated with suspended particulate matter and sediments. The spatial and seasonal variations of heavy metal loads are controlled by suspended sediment concentrations as well as water $\mathrm{pH}$, which controls the absorbance of heavy metals [11].

The spatial distribution of sediments in a reservoir is not uniform [12]. Toward the dam, sediments are usually more fine-grained and lithologically uniform [13]. The heavy metals concentrations generally increased with the decrease of particle size and increase of organic matter. The concentration of heavy metals in 
suspended sediments increase along the reservoir [14]. The distribution of heavy metals in reservoirs depends on some factors such as characteristics, amount, and type of input water. Varol [15] shows the highest metal concentrations at sites located at stream entrances to reservoirs. Similar results are presented by El-Amier [16] indicating that the highest concentrations of heavy metals are near drains. Chen et al. [17] shows that heavy metals concentrations were higher downstream of the dam. The heavy metals can be released from the bottom sediments into the water column from organic matter [18]. Some of them can be accumulated mainly in plant roots, and only a small fraction of them taken up by roots can by allocated to stems and leaves [19].

Bottom sediments are a good indicator of the environmental characteristics of the surrounding area. By documenting the role of natural and anthropogenic factors in determining their quantity, particle size distribution, chemical composition, and physical and chemical properties [20]. In comparison to water concentrations, heavy metal contents in sediments are indicators of the long-term accumulation of trace elements in water bodies [21]. Heavy metals are non-biodegradable; they are not removed from water as a result of self-purification. Sediment quality is an important indicator that enables aquatic ecosystem variations [22]. Sediments have been used as an important tool to assess the health status of aquatic ecosystems [23].

Sediments bottom contamination from heavy metals was investigated using single and integrated pollution indices: enrichment factor (EF), contamination factor (CF), geoaccumulation index (Igeo), pollution load index (PLI), degree of contamination (DC), metal pollution index (MPI), potential ecological risk index (PERI), Nemerow index (NI), contamination index (Pi), potential eco-risk index (Eri), risk assessment code (RAC), and ecological risk index (RI) [1, 4-5, 16, 24-32]. The application of some indices are widely discussed in literature. Zeng and $\mathrm{Wu}$ [33] shows that $\mathrm{Pi}$, Igeo, and $\mathrm{EF}$ are suitable only for risk assessment of a single metal. Additionally, NI may overestimate the metal pollution degree, and PLI emphasizes the spatial distribution of metals but ignores some metals with low concentrations but high toxicity.

Analysis of heavy metals concentrations in bottom sediments mainly is carried out in relation to grain size and organic matter content [32, 34-35]. Additionally, more detailed analysis refers to the interaction about trace metals in suspended sediments, including those adsorbed to mineral surfaces associated with carbonates, $\mathrm{Fe} / \mathrm{Mn}$ oxides, and organic matter $[1,36]$. The analysis of sediment samples taken from the top layer enables the analysis of spatial distribution of heavy metals concentrations in reservoirs. The analysis of the core sediment samples indicated the temporal distribution of heavy metals [29, 34, 37-38]. Bian et al. [26], Antweiler et al. [39], and Frankowski et al. [40] claimed that to describe and understand the heavy metals cycle in reservoirs it is important to characterize heavy metals concentrations in water, suspended sediments, and bottom sediments in the rivers.

Multivariate statistical techniques such as cluster analysis (CA), principal component analysis (PCA), factor analysis (FA), and canonical correspondence analysis (CCA) - powerful tools for drawing meaningful data reduction and the interpretation of geochemical data - have been widely used in geochemical and ecochemical studies [15]. Multivariate statistical methods have been widely applied to investigate the concentrations, accumulation, and distribution of trace elements in water, soils, and suspended and bottom sediments [1, 29, 32, 41-42]. The multivariate statistical approach is used to identify the sources of heavy metals [11, 31, 43-49]. CA, PCA, and FA have been frequently applied to explore the relationship between constituents andto identify the geochemical behavior and spatial variability between sites $[1,31,45]$. The relationships between heavy metal concentrations and bottom sediment physical properties were determined with the use of the multivariate methods CCA, which represents direct gradient analysis in which heavy metals are directly related to bottom sediment physical properties [50].

The objectives of this study are:

1) Identify the concentration and distribution of trace metals in bottom sediments of the Powa River and Stare Miasto Reservoir.

2) Determine the spatial variations of heavy metals in a river-reservoir system using multivariate statistical techniques.

3) Define the natural and/or anthropogenic sources of these metals in the reservoirs.

4) Determine the relationship between heavy metal content and bottom sediment particle sizes and total organic matter.

\section{Material and Methods}

\section{Study Site Description}

The Powa River is a left tributary to the Warta River, which it joins at $398+800 \mathrm{~km}$. The total drainage area of the basin is $344.48 \mathrm{~km}^{2}$, while the length of the river is $48.23 \mathrm{~km}$. The basin area has a lowland character, and the absolute altitudes of the terrain vary from 92.36 to $187.54 \mathrm{~m}$ a.s.l. The average slope of the basin equals $6.14 \%$, while the mean longitudinal slope is $1.09 \%$ [51]. The area is mainly covered by arable land, occupying $56.8 \%$ of the total basin area. The other forms of land use are forests $(26.2 \%)$, greenery $(15.3 \%)$, and urbanised lands $(1.2 \%)$. The total area of water bodies is $1.46 \mathrm{~km}^{2}$, which - with respect to the total basin area gives the water bodies an index of $0.5 \%$. The density of river network is $2.11 \mathrm{~km} \cdot \mathrm{km}^{-2}$. Most formations occurring within the basin area have granulometric composition: loamy sands $(51 \%)$, sands $(16 \%)$, and light loamy sand $(11 \%)$. Mean annual precipitation in the Powa basin is $547 \mathrm{~mm}$ and the average annual temperature is $9.4^{\circ} \mathrm{C}$. 
On the basis of hydrological data from the Posoka gauge station collected in 1974-2014, the flows vary from 0.012 to $42.60 \mathrm{~m}^{3} \cdot \mathrm{s}^{-1}$. The mean annual flow is $1.20 \mathrm{~m}^{3} \cdot \mathrm{s}^{-1}$. The average unit outflow from the basin is $3.47 \mathrm{dm}^{3} \cdot \mathrm{s}^{-1} \cdot \mathrm{km}^{-2}$. The average annual outflow in 1974-2014 was $37.69 \cdot 10^{6} \mathrm{~m}^{3}$.

The Stare Miasto Reservoir was built in 2006. Its length is $4.5 \mathrm{~km}$ and depth varies from 1.2 to $5.7 \mathrm{~m}$ near the main dam [52]. The area of inundation in normal conditions is 90.68 ha, and total capacity of the reservoir is $2.159 \cdot 10^{6} \mathrm{~m}^{3}$ [53]. The object has a twostage construction. The reservoir is divided in two parts: the main part and the upper sedimentation zone. The main function of the upper part is to store sediment deposits and control of pollutant accumulation [54-55]. Total area of the upper part is 27 ha, and total capacity is $0.294 \cdot 10^{6} \mathrm{~m}^{3}$. The main part of reservoir is designed for water supply and flood protection capacities. Total area of this part of the reservoir is 63.68 ha and total capacity is $1.865 \cdot 10^{6} \mathrm{~m}^{3}$. The water surface level varies from the minimum elevation of $92.70 \mathrm{~m}$ a.s.1. to $94.00 \mathrm{~m}$ a.s.1. Normal water level is $93.50 \mathrm{~m}$ a.s.l. One of the main problems related to the functioning of the reservoir is sediment accumulation. Cumulative volume of deposited sediment after 7 years of operation was $0.026 \cdot 10^{6} \mathrm{~m}^{3}$, which makes for an average accumulation velocity equal to $3.6 \cdot 10^{3} \mathrm{~m}^{3}$.year ${ }^{-1}$. The Stare Miasto Reservoir provides water for irrigation and protection from floods, and maintains the biological flows in the Powa downstream from the reservoir. Since 2015 the water stored in the reservoir has been used to generate electricity in the hydro-power plant.

\section{Sample Collection and Preparation}

The sampling and field surveys took place during November 2011 and September 2016. The total 25 top sediment samples (1-5 cm deep top layer) included 9 samples from the Powa and 16 samples from Stare Miasto (Fig. 1). Bottom samples were collected manually by means of Nurek and Czapla devices and carried within zip-mouthed PVC packages.

Grain size and total organic matter content (TOM) were measured to show the general characteristics of sediment samples. Granulometric analysis was done according to the Casagrande aerometric method modified by Prószyński [56]. This procedure is regulated by the Polish norm [57]. Granulometric analysis was done for all samples by using a grainsize analyzer (LS-13320). Sand $(0.05-2.0 \mathrm{~mm})$, silt $(0.002-0.05 \mathrm{~mm})$, and clay $(<0.002 \mathrm{~mm})$ fractions were determined. Total organic matter (TOM) was measured by the Tiurin method with wet oxidation, followed by titration ferrous ammonium sulphate [56]. The content of the metals was determined in bottom sediment samples after extraction with hydrochloric acid (Merck, Darmstadt, Germany) at a 1:4 ratio [57]. The sample was mineralized at $95^{\circ} \mathrm{C} \pm 5^{\circ} \mathrm{C}$ in a Mars 5 Xpress microwave digestion system (CEM, Matthews, North Carolina, United States).

\section{Chemical Analysis}

The concentrations of $\mathrm{Cd}, \mathrm{Cr}, \mathrm{Cu}, \mathrm{Pb}, \mathrm{Ni}$, and $\mathrm{Zn}$ in the bottom sediment samples were determined by acetylene-air flame atomization (F-AAS) using a fast

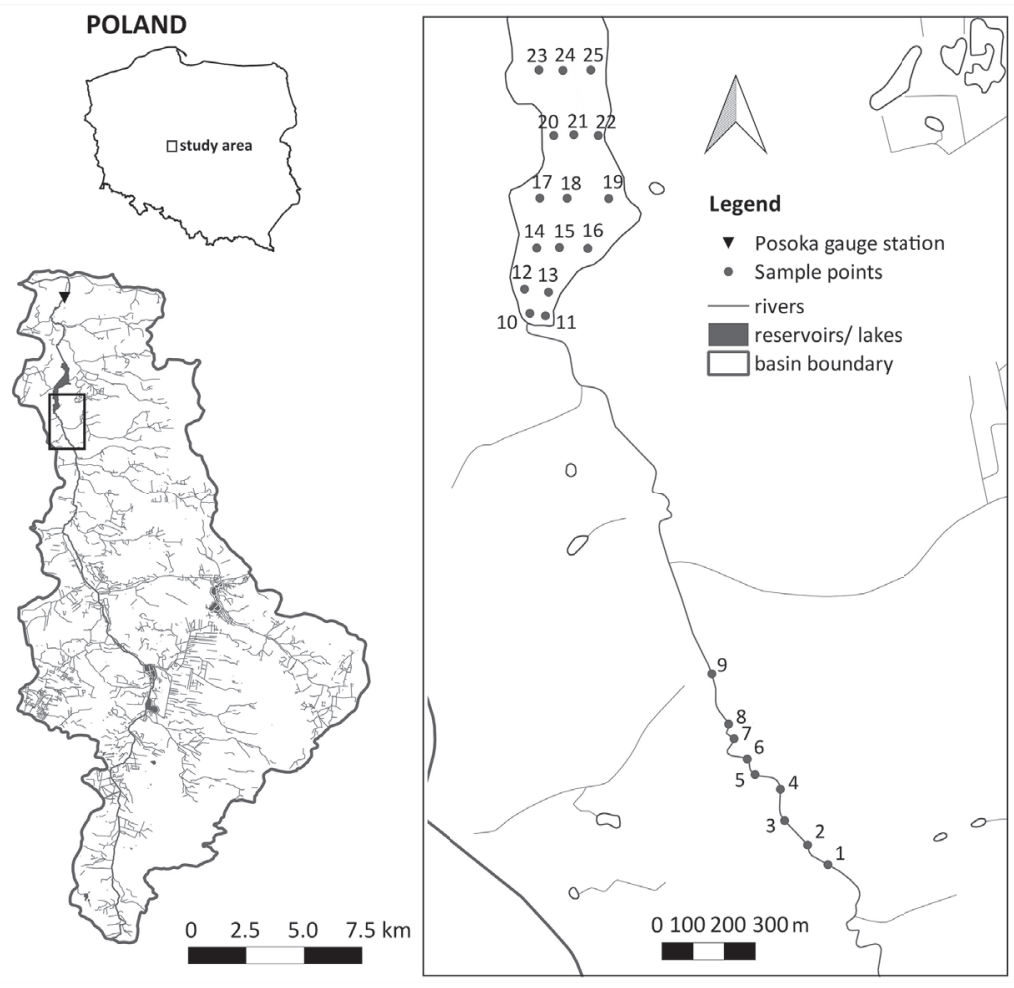

Fig. 1. Study site location. 
sequential SpectrAA 280FS manufactured by Varian (Mulgrave, Victoria, Australia) and using an inductively coupled plasma mass spectrometer (ICP-MS) (Agilent Technologies 8800 Triple Quad, Japan). The analytical procedure is described in previous papers [59-60].

\section{Reagents and Certified Reference Material}

The reagents used were analytically pure, and the water was purified to the resistivity of $18.2 \mathrm{M} \Omega \cdot \mathrm{cm}$ (at $25^{\circ} \mathrm{C}$ ) in a Direct-Q3 Ultrapure Water Systems apparatus (Millipore, France). During the determinations by the AAS and ICP-MS techniques, standard solutions produced by Merck (Merck, Darmstadt, Germany) and VHG Labs (Manchester, England) were used. We measured the following certified materials: SRM 1643e (National Institute of Standards and Technology, USA) and CRM 027-050 (US), and high compliance with reference values was found.

\section{Statistical Analysis}

Statistical differences between the heavy metals concentrations in samples of bottom sediments in river and reservoir were analysed by nonparametric KruskalWallis and Dunn's tests $(\mathrm{p} \leq 0.05)$. The same method was used in order to reveal differences in physical properties of sediment samples. Relationships between concentrations of total organic matter, grain size, and heavy metals were analysed using Spearman's rank correlation analysis.

Before the statistical analysis using multivariate statistical techniques the data are log-transformed to obtain a normal distribution. The normality of analysed features was checked by Shapiro-Wilk's W test [19]. In order to avoid misclassification due to wide differences in data dimensionality, the CA and PCA were applied on standardized data through z-scale transformation [61-62].

CA was applied to group samples into categories or clusters on the basis of similarities and dissimilarities in heavy metals concentrations and physical properties. CA was performed using squared Euclidean distances as a measure of similarity and Ward's method to obtain dendrograms [41]. PCA was employed to identify sources of heavy metals. The number of significant principal components was selected on the basis of a Kaiser criterion of eigenvalues higher than 1. CA and PCA were conducted using Statistica 13.1. CCA was applied to analyze the interactions between heavy metal concentration and grain size and total organic matter content with respect to sample site location $[1,63]$. CCA was conducted using Canoco 4.5 .

\section{Results and Discussion}

\section{Results}

The concentrations of heavy metals in bottom sediments sampled from river and reservoir are presented
Table 1. Content of heavy metals $\left(\mathrm{mg} \mathrm{kg}^{-1} \mathrm{~d}\right.$.m.) in bottom sediments at Powa River and Stare Miasto pre-dam reservoir study sites (minimum, maximum, mean, and standard deviation).

\begin{tabular}{|c|c|c|c|}
\hline Parameters & $\begin{array}{c}\text { River } \\
(\mathrm{N}=9)\end{array}$ & $\begin{array}{c}\text { Reservoir } \\
(\mathrm{N}=16)\end{array}$ & $\begin{array}{c}\text { Average } \\
(\mathrm{N}=25)\end{array}$ \\
\hline $\mathrm{Cr}$ & $0.28-0.62$ & $0.06-0.74$ & $0.06-0.88$ \\
& $0.39 \pm 0.11$ & $0.34 \pm 0.21$ & $0.36 \pm 0.18$ \\
\hline \multirow{2}{*}{$\mathrm{Ni}^{1,2}$} & $0.33-0.61$ & $0.96-5.25$ & $0.33-5.25$ \\
& $0.47 \pm 0.09$ & $2.66 \pm 1.48$ & $1.87 \pm 1.59$ \\
\hline \multirow{2}{*}{$\mathrm{Cu}^{1,2}$} & $0.41-1.23$ & $1.03-2.88$ & $0.41-2.88$ \\
& $0.80 \pm 0.27$ & $1.71 \pm 0.57$ & $1.39 \pm 0.65$ \\
\hline \multirow{2}{*}{$\mathrm{Zn}^{1,2}$} & $3.05-6.18$ & $3.38-21.2$ & $3.05-21.2$ \\
& $5.04 \pm 0.91$ & $10.9 \pm 5.50$ & $8.84 \pm 5.26$ \\
\hline \multirow{2}{*}{$\mathrm{Cd}^{2}$} & $0.16-0.39$ & $0.02-0.80$ & $0.02-0.80$ \\
& $0.27 \pm 0.07$ & $0.33 \pm 0.28$ & $0.31 \pm 0.23$ \\
\hline \multirow{2}{*}{$\mathrm{Pb}^{1,2}$} & $0.64-1.03$ & $0.47-4.96$ & $0.47-4.96$ \\
& $0.76 \pm 0.12$ & $3.17 \pm 1.49$ & $2.30 \pm 1.67$ \\
\hline
\end{tabular}

in Table 1. The results showed that the mean concentration of heavy metals in the river and reservoir bottom sediments followed the order $\mathrm{Zn}>\mathrm{Cu}>\mathrm{Pb}>\mathrm{Ni}>\mathrm{Cr}>\mathrm{Cd}$ and $\mathrm{Zn}>\mathrm{Pb}>\mathrm{Ni}>\mathrm{Cu}>\mathrm{Cr}>\mathrm{Cd}$, respectively. The levels of all investigated elements were affected by sampling location. The highest variability in heavy metal concentrations was noted in reservoir bottom sediments, which contained the highest average concentrations of $\mathrm{Ni}\left(2.66 \mathrm{mg} \mathrm{kg}^{-1} \mathrm{~d} . \mathrm{m}\right.$.), $\mathrm{Cu}$ (1.71 mg kg-1 d.m.), Zn (10.9 mg kg-1 d.m.), and $\mathrm{Pb}$ (3.17 $\mathrm{mg} \mathrm{kg}^{-1}$ d.m.) (Table 1). Concentration levels of Ni, $\mathrm{Cu}, \mathrm{Zn}$, and $\mathrm{Pb}$ in reservoir bottom sediments were from 2.1 to 5.7 times higher than in the river. The differences were statistically significant on the level of $p \leq 0.05$ (significant differences in the Kruskal-Wallis test). A reverse situation was noted in respect to $\mathrm{Cr}$ and $\mathrm{Cd}$, which was found on the same concentrations level in river and reservoir. The effect of bottom sediment physical properties on metal concentrations was analysed with the use of Spearman's rank correlation coefficient. The analysis shows that sediment bottom physical properties that influence $\mathrm{Ni}, \mathrm{Cu}$, and $\mathrm{Zn}$ content may be put in the

Table 2. Spearman's rank correlation analysis of relationships between metal concentrations and physical properties of bottom sediments.

\begin{tabular}{|c|c|c|c|c|}
\hline & TOC & Sand & Silt & Clay \\
\hline $\mathrm{Cr}$ & 0.09 & 0.15 & -0.26 & 0.08 \\
\hline $\mathrm{Ni}$ & $\mathbf{0 . 8 0}$ & $\mathbf{- 0 . 8 9}$ & $\mathbf{0 . 8 4}$ & $\mathbf{0 . 8 3}$ \\
\hline $\mathrm{Cu}$ & $\mathbf{0 . 6 4}$ & $\mathbf{- 0 . 7 3}$ & $\mathbf{0 . 6 7}$ & $\mathbf{0 . 7 2}$ \\
\hline $\mathbf{Z n}$ & $\mathbf{0 . 5 9}$ & $\mathbf{- 0 . 7 2}$ & $\mathbf{0 . 6 9}$ & $\mathbf{0 . 7 3}$ \\
\hline $\mathrm{Cd}$ & 0.27 & -0.22 & 0.17 & 0.20 \\
\hline $\mathrm{Pb}$ & $\mathbf{0 . 7 0}$ & $\mathbf{- 0 . 7 2}$ & $\mathbf{0 . 6 7}$ & $\mathbf{0 . 7 9}$ \\
\hline
\end{tabular}

Bold values indicate significant correlation coefficients $(\mathrm{p} \leq 0.05)$ 

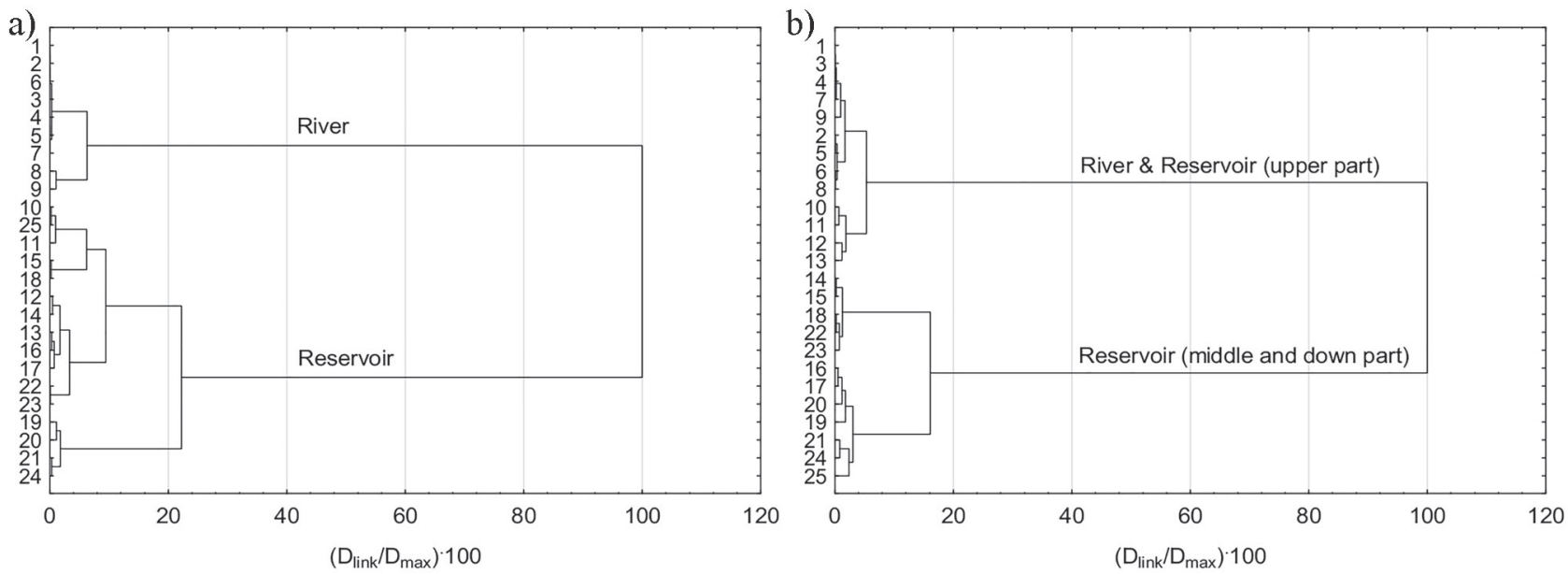

Fig. 2. Dendrogram showing clustering of sampling sites on the basis of bottom sediment physical properties a) and heavy metals concentrations b).

following decreasing order: clay $>$ silt $>$ organic matter (Table 2). A somewhat different situation was noted in respect to $\mathrm{Pb}$. The $\mathrm{Pb}$ concentration was positively correlated with sediment bottom properties in the following decreasing order: clay $>$ organic matter $>$ silt. The concentrations of $\mathrm{Ni}, \mathrm{Cu}, \mathrm{Zn}$, and $\mathrm{Pb}$ were negatively correlated with sand fraction. In respect to $\mathrm{Cr}$ and $\mathrm{Cd}$, no relationships between physical parameters of bottom sediments were observed.

CA was applied to the data set of the river and reservoirs to group the similar sampling sites (spatial variability). Spatial CA rendered a dendrogram (Figs 2a-b) where all 25 sampling sites were grouped into two statistically significant clusters based on physical properties (Fig. 2a) and heavy metals concentrations (Fig. 2b). Significant linkage distance $\left(\mathrm{D}_{\text {link }} / \mathrm{D}_{\text {max }}\right) \cdot 100<25$ indicated a relatively high degree of independence for clusters. Bottom sediment samples from the river were homogeneous and were characterized by low variability of organic matter and sand fraction content. In samples 1 to 7 no silt and clay fractions were detected and in samples 8 and 9 the silt fractions were only 3\%. Greater variation in physical parameters of bottom sediments were observed in the reservoir (Table 3). The TOC content in bottom sediment samples varied from 1.01 to 18.8 and the average was 11.9 times higher than in the river. The silt and clay content varied from 3.0 to 39.0 and from 1.0 to 8.0 , respectively. Sediment distribution depends on morphometric parameters of the pre-dam reservoir such as depth, area, and shape, and hydrological parameters such as retention time and location of hydraulic structures (inlet and outlet). The spatial distribution of sediments in a reservoir is not uniform. Generally toward the dam, sediments are usually fine-grained and lithologically uniform (Fig. 2a).

Cluster analysis with respect to heavy metal concentrations has shown that 25 points can be subdivided into two groups with different heavy metal content (Fig. 2b). In Cluster 1 (sites 1 to 9 of the river and sites 10 to 13 of the upper part of the reservoir), and the average concentrations of $\mathrm{Ni}, \mathrm{Cu}, \mathrm{Zn}$, and $\mathrm{Pb}$ were higher than in Cluster 2. $\mathrm{Cr}$ and $\mathrm{Cd}$ concentrations in Clusters 1 and $2 \mathrm{did}$ not differ significantly. The low concentrations of $\mathrm{Ni}, \mathrm{Cu}$, $\mathrm{Zn}$, and $\mathrm{Pb}$ in samples 10 to 13 result from the hydraulic conditions for sedimentation of silt, clay, and TOM in the reservoir inlet. The sites located in the middle and lower parts of the reservoir (Cluster 2) are characterised by higher variability of heavy metals concentrations. The trace element concentrations generally increased with the decrease of particle size and increase of organic matter content. Generally the concentration of heavy metals increases along the reservoir, which is caused by the natural sedimentation process.

PCA was employed to identify sources of heavy metals. In this study, two components (PCs) with eigenvalues higher than one were obtained. $\mathrm{PCl}$ and PC2 explained about $86.49 \%$ of the total variance in the heavy metals concentration data set. The corresponding PCs, variable loadings, and the explained variance are presented in Table 4. Component 1 (PC1), which accounted for $66.08 \%$ of the total variance, had strong positive loadings $(>0.70)$ on $\mathrm{Ni}, \mathrm{Cu}, \mathrm{Zn}$, and $\mathrm{Pb}$, and moderate positive loading $(>0.50)$ on $\mathrm{Cd}$. $\mathrm{PC} 2$, which

Table 3. Bottom sediment physical properties.

\begin{tabular}{|c|c|c|c|}
\hline $\begin{array}{c}\text { Property of } \\
\text { bottom sediments }\end{array}$ & $\begin{array}{c}\text { River } \\
(\mathrm{N}=9)\end{array}$ & $\begin{array}{c}\text { Reservoir } \\
(\mathrm{N}=16)\end{array}$ & $\begin{array}{c}\text { Average } \\
(\mathrm{N}=25)\end{array}$ \\
\hline $\mathrm{TOC}^{1,2}$ & $\begin{array}{c}0.07-1.76 \\
0.50 \pm 0.50\end{array}$ & $\begin{array}{c}1.01-18.8 \\
5.94 \pm 5.00\end{array}$ & $\begin{array}{c}0.07-18.8 \\
3.98 \pm 4.77\end{array}$ \\
\hline Fractions (mm): & & & \\
\hline sand $2.0-0.05^{1,2}$ & $97.0-100$ & $58.0-95.0$ & $58.0-100$ \\
& $99.3 \pm 1.32$ & $84.1 \pm 9.5$ & $89.6 \pm 10.6$ \\
\hline silt $0.05-0.002^{1,2}$ & $0.0-3.0$ & $3.0-39.0$ & $0.0-39.0$ \\
& $0.67 \pm 1.33$ & $12.4 \pm 9.3$ & $8.2 \pm 9.4$ \\
\hline clay $<0.002^{1,2}$ & $0.0-0.0$ & $1.0-8.0$ & $0.0-8.0$ \\
& $0.0 \pm 0.0$ & $3.5 \pm 2.6$ & $2.2 \pm 2.7$ \\
\hline
\end{tabular}


Table 4. Initial eigenvalues and rotated component matrix of heavy metals concentrations in bottom sediments.

\begin{tabular}{|c|c|c|}
\hline & \multicolumn{2}{|c|}{ Component } \\
\hline Elements & PC1 & PC2 \\
\hline Eigenvalue & 3.965 & 1.225 \\
\hline Total variance \% & 66.08 & 20.42 \\
\hline Cumulative variance \% & 66.08 & 86.49 \\
\hline $\mathrm{Cr}$ & -0.001 & $\mathbf{0 . 9 4 2}$ \\
\hline $\mathrm{Ni}$ & $\mathbf{0 . 9 0 4}$ & 0.266 \\
\hline $\mathrm{Cu}$ & $\mathbf{0 . 8 8 3}$ & -0.104 \\
\hline $\mathrm{Zn}$ & $\mathbf{0 . 8 6 7}$ & 0.396 \\
\hline $\mathrm{Cd}$ & 0.531 & $\mathbf{0 . 7 8 6}$ \\
\hline $\mathrm{Pb}$ & $\mathbf{0 . 8 7 2}$ & 0.237 \\
\hline
\end{tabular}

Bold and underline values indicate strong and moderate loadings, respectively.

accounted for $20.42 \%$ of the total variance, had strong positive loadings on $\mathrm{Cr}$ and $\mathrm{Cd}$ (Table 4). Very small concentrations of $\mathrm{Cr}$ in the river-reservoir system reflected natural background levels. In addition, $\mathrm{Cr}$ shows relatively small spatial variability among the 25 sampling sites located in the river and reservoir. Therefore, the $\mathrm{Cr}$ are predominantly derived from geogenic sources. The concentrations of $\mathrm{Ni}, \mathrm{Cu}, \mathrm{Zn}$, and $\mathrm{Pb}$ and their spatial variability demonstrated that these metals probably originate from anthropogenic sources (Fig. 3). The strong positive loadings of $\mathrm{Cd}$ with $\mathrm{PC} 2$ and moderated with PC1 suggest a combination of anthropogenic and natural sources. PCA analysis suggests that other factors than the content of silt and clay fraction and total organic matter content may affect $\mathrm{Cr}$ transportation in the river-reservoir system.

We used CCA to assess the relationship between the physical properties of bottom sediments and heavy metals

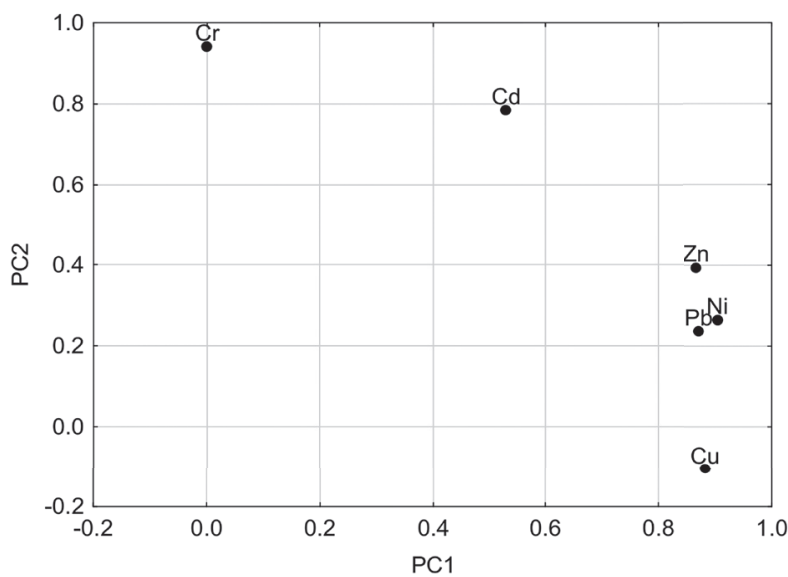

Fig. 3. PCA results of heavy metals concentrations in bottom sediments.
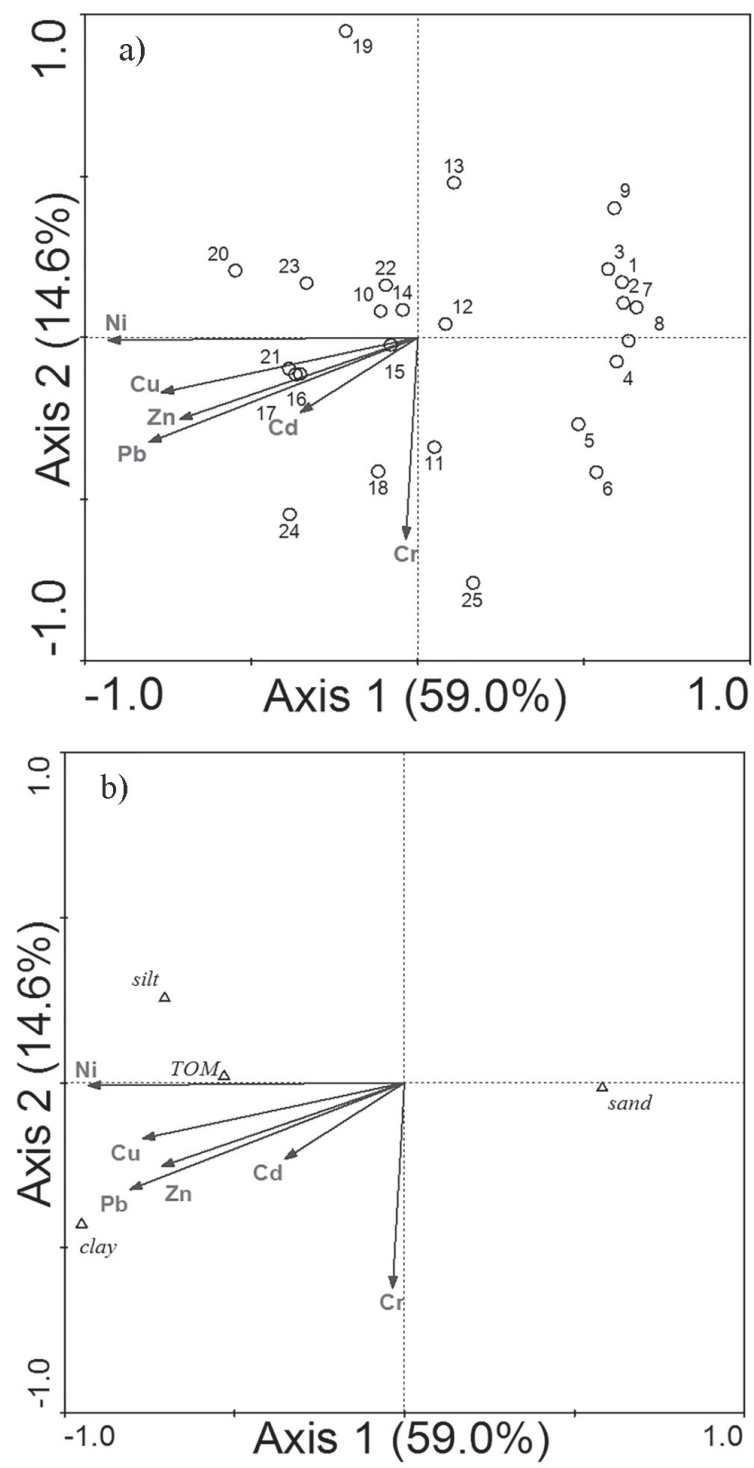

Fig. 4. Canonical correspondence analysis biplots of heavy metals concentrations associated with sample site location and bottom sediment physical properties.

concentrations. CCA analysis explained $54.3 \%$ of the data variation. The first two axes and confirmed sampling sites were divided according to physical properties of bottom sediments (Fig. 4a). The river (sites 1 to 9) and reservoir (10 to 25 ) samples were separated mainly by the first axis. The negative value on the first axis indicated high silt, clay, and TOM contents, and positive value indicated high content of sand fraction. The river sites were more homogenous, with sites 1 to 9 placed close to each other. The distance between the sites in the diagram approximates the dissimilarity in sediment physical composition. Bottom sediment samples 1 to 9 were characterised by high content of sand and low content of silt and TOM. Sample sites located in the reservoir were more heterogeneous due to hydraulic condition variability, which has a great impact on the sedimen-tation process. Bottom sediment samples containing more silt and clay 
fractions and organic matter were generally characterized by higher concentrations of heavy metals. The similar directions of $\mathrm{Ni}, \mathrm{Pb}, \mathrm{Cu}$, and $\mathrm{Cd}$ factors and the opposite direction of $\mathrm{Cr}$ (Fig. 4b). The angles between heavy metals arrows indicate correlations between individual heavy metals. This result suggest a different source, and driving forces determine its concentration in bottom sediments.

\section{Discussion}

The obtained results confirmed the analysis of [1-2] that suspended sediments are the principal factor for heavy metals transport in the river-reservoir system. Concentrations of heavy metals in the reservoir sediments were higher than those in the bottom sediments of the river where it was formed. Concentrations of heavy metals in bottom sediments in the Powa River above the reservoir were characterized by lower spatial variability. Heavy metal concentrations in the reservoir were characterized by high variability, which was primarily related to organic matter, silt, and clay content. In general, the higher the organic matter content as well as silt and clay contents, the greater the concentration of heavy metals. Similar findings on statistical correlations between soil organic matter, silt, and clay were reported by [64-65]. El-Sayed et al. [27] showed that this trend is not proven for all elements, which means that grain size is not the only factor affecting heavy metal concentrations. Additionally, lithogenic sources and mineralogical composition of sediments as well as physical, chemical, and biological processes are other factors that share in controlling the sediment-heavy metal content.

In general, heavy metal concentrations in bottom sediments rise along the reservoir, which is related to the sedimentation process. At the inlet of the reservoir the sand fraction was mostly sedimented, while the middle and lower parts saw silt and clay fractions. Similar findings were reported by Klaver et al. [14], who showed that the concentration of heavy metals increases along the reservoir. Sedláček et al. [13] indicated that reservoir sediments are usually more fine-grained and lithologically uniform. The variability of the sedimentation process is an individual feature of each reservoir that depends on morphometric parameters of the reservoir, water exchange time, and operating conditions. Additionally, the distribution of heavy metals in reservoirs depends on some factors such as amount and characteristics of rivers water. As shown by the present analysis, the relatively high flow velocities at the inlet part of Stare Miasto Reservoir result in unfavorable conditions for the sedimentation of silt, clay, and TOM. This translates into low concentrations of heavy metals in bottom sediments in the inlet part. The concentrations of heavy metals were close to those recorded in the rivers. Slightly different results were obtained by Varol [15] and El-Amier [16], who show that the highest metal concentrations at the sites were located at the entrances of streams and drains. Additionally, the distribution of heavy metals in reservoirs depends on some factors such as characteristics and amount of input water.

The use of CA allows for the division of measurement sites into homogeneous groups in terms of heavy metals concentrations, which allows for a better understanding of their circulation in the river-reservoir system. Additionally, PCA enables the determination of potential sources of heavy metals in sediment and CCA provides a comprehensive assessment of the relationship between physical properties of bottom sediments and heavy metals concentrations.

\section{Conclusions}

1. Heavy metals concentrations in the bottom sediments of the reservoir were higher than in the bottom sediments and were characterized by higher variability.

2. Concentrations of heavy metals at the inlet to reservoir were similar to those recorded in the river.

3. Silt, clay, and total organic matter content have decisive influence on heavy metal concentrations of bottom sediments.

4. Suspended sediments have a decisive influence on heavy metal circulation in river system reservoir retention.

5. Spatial variability of heavy metal concentrations in bottom sediments results from the hydraulic parameters of the reservoir, which determines the sedimentation process.

6. Low spatial variability of $\mathrm{Cr}$ concentrations and no relationship with the content of silt, clay, and total organic matter content suggests their geogenic sources, or different driving forces determine its concentration.

\section{Acknowledgements}

This research is supported by project No. N N305 296740 sponsored by the National Science Centre in 2010-13.

\section{References}

1. JI H., DING H., TANG L., LI C., GAO Y., BRIKI M. Chemical composition and transportation characteristic of trace metals in suspended particulate matter collected upstream of a metropolitan drinking water source, Beijing. Journal of Geochemical Exploration, 169, 123, 2016.

2. WANG H., ZHAO Y., LIANG D., DENG Y., PANG Y. 30+ year evolution of $\mathrm{Cu}$ in the surface sediment of Lake Poyang, China. Chemosphere, 168, 1604, 2017.

3. BEGY R.C., PREOTEASA L., TIMAR-GABOR A., MIHĂIESCU R., TĂNĂSELIA C., KELEMEN S., SIMON H. Sediment dynamics and heavy metal pollution history 
of the Cruhlig Lake (Danube Delta, Romania). Journal of Environmental Radioactivity, 153, 167, 2016.

4. BING H., ZHOU J., WU Y., WANG X., SUN H., LI R. Current state, sources, and potential risk of heavy metals in sediments of Three Gorges Reservoir, China. Environmental Pollution, 214, 485, 2016.

5. HANIF N., EQANI S.A.M.A.S., ALI S.M., CINCINELLI A., ALI N., KATSOYIANNIS I.A., TANVEER Z.I., BOKHARI H. Geo-accumulation and enrichment of trace metals in sediments and their associated risks in the Chenab River, Pakistan. Journal of Geochemical Exploration, 165, 62, 2016.

6. KUCUKSEZGIN F., ULUTURHAN E., BATKI H. Distribution of heavy metals in water, particulate matter and sediments of Gediz River (Eastern Aegean). Environmental Monitoring and Assessment, 141 (1), 213, 2008.

7. SIDERN S., TREMÖHLEN M., DSIKOWITZKY L., GRONEN L., SCHWARZBAUER J., SIREGAR T.H., ARIYANI F., IRIANTO H.E. Heavy metals in river and coast sediments of the Jakarta Bay region (Indonesia)-Geogenic versus anthropogenic sources. Marine Pollution Bulletin, 110 (2), 624, 2016.

8. WILDI W., DOMINIK J., LOIZEAU J.L., THOMAS R.L., FAVARGER P.Y., HALLER L., PERROUD A., PEYTREMANN C. River, reservoir and lake sediment contamination by heavy metals downstream from urban areas of Switzerland. Lakes \& Reservoirs: Research \& Management, 9 (1), 75, 2004.

9. AMIN B., ISMAIL A., ARSHAD A., YAP C.K., KAMARUDIN M.S. Anthropogenic impacts on heavy metal concentrations in the coastal sediments of Dumai, Indonesia. Environmental Monitoring and Assessment, 148 (1), 291, 2009.

10. ZHENG N.A., WANG Q., LIANG Z., ZHENG D. Characterization of heavy metal concentrations in the sediments of three freshwater rivers in Huludao City, Northeast China. Environmental Pollution, 154 (1), 135, 2008.

11. YANG Z., XIA X., WANG Y., JI J., WANG D., HOU Q., YU T. Dissolved and particulate partitioning of trace elements and their spatial-temporal distribution in the Changjiang River. Journal of Geochemical Exploration, 145, 114, 2014

12. CLARK E.V., ODHAIAMBO B.K., YOON S., PILATI L. Hydroacoustic and spatial analysis of sediment fluxes and accumulation rates in two Virginia reservoirs, USA. Environmental Science and Pollution Research, 22 (11), 8659, 2015

13. SEDLÁČEK J., BÁBEK O., KIELAR O. Sediment accumulation rates and high-resolution stratigraphy of recent fluvial suspension deposits in various fluvial settings, Morava River catchment area, Czech Republic. Geomorphology, 254, 73, 2016.

14. KLAVER G., VAN OS B., NEGREL P., PETELET-GIRAUD E. Influence of hydropower dams on the composition of the suspended and riverbank sediments in the Danube. Environmental Pollution, 148 (3), 718, 2007.

15. VAROL M. Dissolved heavy metal concentrations of the kralkizi, dicle and batman dam reservoirs in the tigris river basin, turkey. Chemosphere, 93 (6), 954, 2013.

16. EL-AMIER Y.A., ELNAGGAR A.A., EL-ALFY M.A. Evaluation and mapping spatial distribution of bottom sediment heavy metal contamination in Burullus Lake, Egypt. Egyptian Journal of Basic and Applied Sciences, 4 (1), 55, 2016.

17. CHEN S., CHEN B., SU M. An estimation of ecological risk after dam construction in LRGR, China: Changes on heavy metal pollution and plant distribution. Procedia Environmental Sciences, 5, 153, 2011.

18. LOSKA K., WIECHUŁA D. Application of principal component analysis for the estimation of source of heavy metal contamination in surface sediments from the Rybnik Reservoir. Chemosphere, 51 (8), 723, 2003.

19. POLECHOŃSKA L., KLINK A. Trace metal bioindication and phytoremediation potentialities of Phalaris arundinacea L. (reed canary grass). Journal of Geochemical Exploration, 146, 27, 2014.

20. RZĘTAŁA M., JAGUŚ A., RZĘTAŁA M.A., RAHMONOV O., RAHMONOV M., KHAK V. Variations in the chemical composition of bottom deposits in anthropogenic lakes. Polish Journal of Environmental Studies, 22 (6), 1799, 2013.

21. BALDANTONI D., MAISTO G., BARTOLI G., ALFAMI A. Analyses of three native aquatic plant species to assess spatial gradients of lake trace element contamination. Aquatic botany, 83 (1), 48, 2005.

22. BURTON JR A.G., BAUDO R., BELTRAMI M., ROWLAND C. Assessing sediment contamination using six toxicity assays. Journal of Limnology, 60 (2), 263, 2001.

23. BIRCH G.F., Taylor S.E., Matthai C. Small-scale spatial and temporal variance in the concentration of heavy metals in aquatic sediments: a review and some new concepts. Environmental Pollution, 113 (3), 357, 2001.

24. ALI M.M., ALI M.L., ISLAM M.S., RAHMAN M.Z. Preliminary assessment of heavy metals in water and sediment of Karnaphuli River, Bangladesh. Environmental Nanotechnology, Monitoring \& Management, 5, 27, 2016.

25. AUDRY S., SCHÄFER J., BLANC G., JOUANNEAU J.M. Fifty-year sedimentary record of heavy metal pollution $(\mathrm{Cd}$, $\mathrm{Zn}, \mathrm{Cu}, \mathrm{Pb}$ ) in the Lot River reservoirs (France). Environmental Pollution, 132 (3), 413, 2004.

26. BIAN B., ZHOU Y., FANG B.B. Distribution of heavy metals and benthic macroinvertebrates: Impacts from typical inflow river sediments in the Taihu Basin, China. Ecological Indicators, 69, 348, 2016.

27. EL-SAYED S.A., MOUSSA E.M.M., EL-SABAGH M.E.I. Evaluation of heavy metal content in Qaroun Lake, El-Fayoum, Egypt. Part I: Bottom sediments. Journal of Radiation Research and Applied Sciences, 8 (3), 276, 2015.

28. GOHER M.E., FARHAT H.I., ABDO M.H., SALEM S.G. Metal pollution assessment in the surface sediment of Lake Nasser, Egypt. The Egyptian Journal of Aquatic Research, 40 (3), 213, 2014.

29. GU J., SALEM A., CHEN Z. Lagoons of the Nile delta, Egypt, heavy metal sink: With a special reference to the Yangtze estuary of China. Estuarine, Coastal and Shelf Science, 117, 282, 2013.

30. MOHAMADEN M.I.I., KHALIL M.K., DRAZ S.E.O., HAMODA A.Z.M. Ecological risk assessment and spatial distribution of some heavy metals in surface sediments of New Valley, Western Desert, Egypt. The Egyptian Journal of Aquatic Research, 43 (1), 31, 2017.

31. ZAHRA A., HASHMI M.Z., MALIK R.N., AHMED Z. Enrichment and geo-accumulation of heavy metals and risk assessment of sediments of the Kurang Nallah-Feeding tributary of the Rawal Lake Reservoir, Pakistan. Science of the Total Environment, 470, 925, 2014.

32. ZHANG W., FENG H., CHANG J., QU J., XIE H., YU L. Heavy metal contamination in surface sediments of Yangtze River intertidal zone: An assessment from different indexes. Environmental Pollution, 157 (5), 1533, 2009. 
33. ZENG H.A., WU J.L. Sedimentary records of heavy metal pollution in Fuxian Lake, Yunnan Province, China: intensity, history, and sources. Pedosphere, 19, 562, 2009.

34. CHEN Z., SALEM A., XU Z., ZHANG W. Ecological implications of heavy metal concentrations in the sediments of Burullus Lagoon of Nile Delta, Egypt. Estuarine, Coastal and Shelf Science, 86 (3), 491, 2010.

35. SOUZA V.A., Wasserman J.C. Distribution of heavy metals in sediments of a tropical reservoir in Brazil: Sources and fate. Journal of South American Earth Sciences, 63, 208, 2015.

36. HUA L., MA H., JI J. Concentration and distribution characteristic of main toxic metals in suspended particle material in Nanjing reach, Changjiang River. Environmental Monitoring and Assessment, 173 (1), 361, 2011.

37. SEDLÁČEK J., BÁBEK O., NOVÁKOVÁ T. Sedimentary record and anthropogenic pollution of a complex, multiple source fed dam reservoirs: An example from the Nové Mlýny reservoir, Czech Republic. Science of the Total Environment, 574, 1456, 2017.

38. SKWIERAWSKI A., SIDORUK M. Heavy metal concentrations in the sediment profiles of the anthropogenically transformed plociduga reservoir. Ecological Chemistry and Engineering S, 21 (1), 79, 2014.

39. ANTWEILER R.C., TAYLOR H.E., ALPERS C.N. Distribution and geochemistry of selected trace elements in the Sacramento River near Keswick Reservoir. Chemical Geology, 298, 70, 2012.

40. FRANKOWSKI M., SOJKA M., ZIOŁA-FRANKOWSKA A., SIEPAK M., MURAT-BŁAŻEJEWSKA S. Distribution of heavy metals in the Mala Wełna River system (western Poland). Oceanological \& Hydrobiological Studies, 38 (2), 51, 2009

41. LI S., ZHANG Q. Spatial characterization of dissolved trace elements and heavy metals in the upper Han River (China) using multivariate statistical techniques. Journal of Hazardous Materials, 176 (1), 579, 2010.

42. SOJKA M., SIEPA, M., ZIOŁA A., FRANKOWSKI M., MURAT-BŁAŻEJEWSKA S., SIEPAK J. Application of multivariate statistical techniques to evaluation of water quality in the Mała Wełna River (Western Poland). Environmental Monitoring and Assessment, 147 (1), 159, 2008.

43. IQBAL J., SALEEM M., SHAH M.H. Spatial distribution, environmental assessment and source identification of metals content in surface sediments of freshwater reservoir, Pakistan. Chemie Der Erde - Geochemistry, 76 (1), 171, 2016.

44. KE X., GUI S., HUANG H., ZHANG H., WANG C., GUO W. Ecological risk assessment and source identification for heavy metals in surface sediment from the Liaohe River protected area, China. Chemosphere, 175, 473, 2017.

45. KÜLAHCI F., ŞEN Z. Multivariate statistical analyses of artificial radionuclides and heavy metals contaminations in deep mud of Keban Dam Lake, Turkey. Applied Radiation and Isotopes, 66 (2), 236, 2008.

46. LIU J., YIN P., CHEN, B., GAO F., SONG H., LI M. Distribution and contamination assessment of heavy metals in surface sediments of the Luanhe River Estuary, northwest of the Bohai Sea. Marine Pollution Bulletin, 109 (1), 633, 2016.

47. WANG C., LIU S., ZHAO Q., DENG L., DONG S. Spatial variation and contamination assessment of heavy metals in sediments in the Manwan Reservoir, Lancang River. Ecotoxicology and Environmental Safety, 82, 32, 2012.

48. YALCIN M.G., TUMUKLU A., SONMEZ M., ERDAG D.S. Application of multivariate statistical approach to identify heavy metal sources in bottom soil of the Seyhan River (Adana), Turkey. Environmental Monitoring and Assessment, 164 (1), 311, 2010.

49. ZHOU J., MA D., PAN J., NIE W., WU K. Application of multivariate statistical approach to identify heavy metal sources in sediment and waters: a case study in Yangzhong, China. Environmental Geology, 54 (2), 373, 2008.

50. OBOLEWSKI K., SKORBIŁOWICZ E., SKORBIŁOWICZ M., GLIŃSKA-LEWCZUK K., ASTEL A.M., STRZELCZAK A. The effect of metals accumulated in reed (Phragmites australis) on the structure of periphyton. Ecotoxicology and Environmental Safety, 74 (4), 558, 2011.

51. SOJKA M., SIEPAK M., GNOJSKA E. Assessment of heavy metals concentration in bottom sediments of Stare Miasto Pre-Dam Reservoir on the Powa River. Annual Set the Environment Protection, 15, 1916, 2013 [In Polish].

52. DYSARZ T., WICHER-DYSARZ J. Analysis of flow conditions in the Stare Miasto Reservoir taking into account sediment settling properties. Annual Set The Environment Protection, 15, 584, 2013.

53. WOLIŃSKI J., ZGRABCZYŃSKI J. The Stare Miasto reservoir in the Powa River: Water management rules; „BIPROWODMEL” Sp. z o.o., Poznań, Poland, 2008 [In Polish].

54. DAZBROWSKA J., KACZMAREK H., MARKOWSKA J., TYSZKOWSKI S., KEMPA O., GAŁEZZA M., KUCHARCZYK-MORYL E., MORYL A. Shore zone in protection of water quality in agricultural landscape-the Mściwojów Reservoir, southwestern Poland. Environmental monitoring and assessment, 188 (8), 467, 2016.

55. SOJKA M., JASKUŁA J., WICHER-DYSARZ J., DYSARZ T. Assessment of dam construction impact on hydrological regime changes in lowland river-A case of study: the Stare Miasto reservoir located on the Powa River. Journal of Water and Land Development, 30 (1), 119, 2016.

56. OSTROWSKA A., GAWLIŃSKI S., SZCZUBIAŁKA Z. Methods of analysis and assessment of soil and plant properties. Environmental Protection Institute, Warszawa, Poland, 1991 [In Polish].

57. POLISH STANDARD PN-R-04032. Soil and mineral soil materials-Sampling and determination of particle size distribution. Polish Committee for Standardization, Warszawa, Poland, 1998 [In Polish].

58. LIS J., PASIECZNA A. Geochemical atlas of Poland. Polish Geological Institute, Warszawa, Poland, 1995 [In Polish].

59. CIAZŻELA J., SIEPAK M. Environmental factors affecting soil metals near outlet roads in Poznań, Poland: Impact of grain size, soil depth and wind dispersal. Environmental Monitoring and Assessment, 188 (6), 323, 2016.

60. SIEPAK M., SOJKA M. Application of multivariate statistical approach to identify trace elements sources in surface waters: A case study of Kowalskie and Stare Miasto reservoir, Poland. Environmental Monitoring and Assessment, 189(8), 364, 2017.

61. VAROL M., ŞEN B. Assessment of surface water quality using multivariate statistical techniques: a case study of Behrimaz Stream, Turkey. Environmental Monitoring and Assessment, 159 (1), 543, 2009.

62. VAROL M., GÖKOT B., BEKLEYEN A., ŞEN B. Spatial and temporal variations in surface water quality of the dam reservoirs in the Tigris River basin, Turkey. Catena, 92, 11, 2012.

63. FU J., ZHAO C., LUO Y., LIU C., KYZAS G.Z., LUO Y., ZHAO D., AN S., ZHU H. Heavy metals in surface sediments of the Jialu River, China: Their relations to 
environmental factors. Journal of Hazardous Materials, 270, 102, 2014.

64. GLIŃSKA-LEWCZUK K., BIENIEK A., SOWIŃSKI P., OBOLEWSKI K., BURANDT P., TIMOFTE C.M. Variability of zinc content in soils in a postglacial river valley - a geochemical landscape approach. Journal of Elementology, 19 (2), 861, 2014.
65. SOWIŃSKI P., GLIŃSKA-LEWCZUK K., KALISZ B., ASTEL A. Distribution of heavy metals in soils in postglacial river valley - a geochemical landscape approach. Environmental Engineering and Management Journal, 15(6), 1323, 2016. 